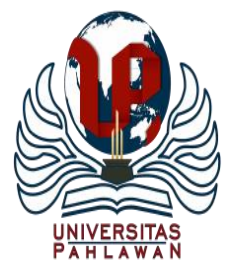

Edukatif : Jurnal Ilmu Pendidikan Volume 3 Nomor 4 Tahun 2021 Halm 1177 - 1184

EDUKATIF: JURNAL ILMU PENDIDIKAN

Research \& Learning in Education

https:/ledukatif.org/index.php/edukatif/index

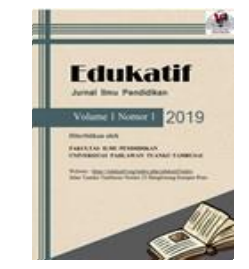

\title{
Penerapan Media Pembelajaran Visual dalam Membangun Motivasi Belajar Siswa Sekolah Dasar
}

\author{
Yonathan Hae $^{1 凶}$, Year Rezeki Patricia Tantu ${ }^{2}$ Widiastuti $^{3}$ \\ Universitas Pelita Harapan, Indonesia ${ }^{1,2,3}$ \\ E-mail : jonathanhae99@gmail.com ${ }^{1}$, year.rezeki@gmail.com² ${ }^{2}$, widiastuti.tc@uph.edu ${ }^{3}$
}

\begin{abstract}
Abstrak
Pemberian media pembelajaran yang tepat sesuai karakteristik anak SD dapat mendorong peningkatan motivasi belajar siswa. Realita yang dialami oleh siswa SD kelas 5 di salah satu sekolah yang ada di Sulawesi Utara adalah siswa kurang aktif dan tidak begitu tertarik kepada penyajian materi dan pertanyaan yang diberikan oleh guru. Hal ini disebabkan kurangnya penggunaan gambar visual dan penjelasan yang dilakukan lebih banyak menggunakan teks. Tujuan dari penelitian ini adalah mendeskripsikan penerapan media pembelajaran visual dalam membangun motivasi belajar siswa SD kelas 5. Metode penelitian yang digunakan adalah deskriptif kualitatif. Penelitian dilakukan pada bulan Juli-Agustus 2020. Teknik pengumpulan data dalam penelitian ini adalah observasi, studi dokumentasi, dan refleksi. Hasil penelitian menunjukkan dengan pemberian media pembelajaran visual yang menekankan kepada prinsip kesederhanaan, penekanan, dan keterpaduan dapat membangun motivasi belajar siswa kelas 5 SD saat belajar. Selain itu, media pembelajaran visual perlu dirancang sesuai dengan tujuan pembelajaran yang ditentukan.
\end{abstract}

Kata Kunci: media pembelajaran visual, motivasi belajar, siswa sekolah dasar.

\begin{abstract}
Providing appropriate learning media according to the characteristics of elementary school children can encourage student learning motivation. The reality experienced by grade 5 elementary school students in one of the schools in North Sulawesi which the students were less active and not really interested in the presentation of the material and questions given by the teacher. This was due to the lack of used of visual images and the explanation used more text. The purpose of this study was to describe the application of visual learning media to build learning motivation of 5th grade elementary school students. The research method used was descriptive qualitative. The research was conducted in July-August 2020. The data collection techniques in this study were observation, documentation study, and reflection. The results showed that the provision of visual learning media that emphasizes the principles of simplicity, emphasis, and integration can build learning motivation for 5 th grade elementary school students while studying. In addition, visual learning media need to be designed in accordance with the specified learning objectives.
\end{abstract}

Keywords: visual learning media, learning motivation, primary student.

Copyright (c) 2021 Yonathan Hae, Year Rezeki Patricia Tantu, Widiastuti

$\triangle$ Corresponding author

Email : jonathanhae99@gmail.com

DOI $\quad$ : https://doi.org/10.31004/edukatif.v3i4.522

ISSN 2656-8063 (Media Cetak)

ISSN 2656-8071 (Media Online)

Edukatif : Jurnal Ilmu Pendidikan Vol 3 No 4 Tahun 2021 p-ISSN 2656-8063 e-ISSN 2656-8071 
1178 Penerapan Media Pembelajaran Visual dalam Membangun Motivasi Belajar Siswa Sekolah Dasar Yonathan Hae, Year Rezeki Patricia Tantu, Widiastuti

DOI: https://doi.org/10.31004/edukatif.v3i4.522

\section{PENDAHULUAN}

Motivasi belajar merupakan salah satu penentu keberhasilan dalam proses pembelajaran. Makki \& Aflahah (2019) mengatakan bahwa motivasi belajar sangat menentukan tingkat pencapaian hasil belajar anak. Ketika siswa memiliki motivasi untuk belajar maka siswa akan memiliki semangat untuk mengeksplorasi pengetahuan yang diberikan, siswa akan berusaha mengembangkan keterampilan dalam dirinya, dan menunjukkan sikap pembelajar yang memiliki rasa ingin tahu terhadap pembelajaran yang diikuti. Motivasi belajar dibutuhkan dalam semua konteks pembelajaran, baik pembelajaran tatap muka maupun pembelajaran daring. Pada masa pandemi Covid-19 ini, sebagian besar sekolah melakukan kegiatan pembelajaran di rumah dengan bantuan jaringan internet. Terbatasnya kegiatan tatap muka di sekolah menuntut dorongan belajar yang tinggi dari setiap siswa agar pembelajaran dapat diikuti dengan maksimal. Motivasi belajar menjadi salah satu faktor yang sangat dibutuhkan selama masa pembelajaran daring sehingga siswa dapat terus terlibat aktif dalam belajar dan pada akhirnya siswa akan memperoleh pembelajaran yang bermakna.

Motivasi dapat diartikan sebagai dorongan psikologis pada seseorang sehingga melakukan tindakan untuk mencapai tujuan tertentu baik secara sadar maupun tidak sadar (Badaruddin, 2015). Berdasarkan pengertian sebelumnya, dapat dikatakan bahwa motivasi belajar merupakan dorongan yang timbul dari dalam diri siswa yang dapat membangkitkan semangat belajar untuk mencapai tujuan pembelajaran. Secara umum terdapat dua faktor yang mempengaruhi motivasi belajar siswa, yaitu rangsangan yang datang dari luar diri siswa (ekstrinsik) dan kemauan yang datang dari dalam diri sendiri (intrinsik) (Emda, 2018). Dalam penelitian yang dilakukan di salah satu SD di Magelang ditemukan bahwa motivasi belajar pada siswa tidak hanya diperoleh melalui faktor ekstrinsik sendiri maupun faktor intrinsik saja, tetapi perlu kombinasi dari kedua faktor tersebut (Indah, Yanti, Arifi, Pawestri, \& Hermahayu, 2020).

Indikator dari adanya motivasi belajar siswa adalah ada rasa perhatian atau ketertarikan terhadap pembelajaran yang diberikan oleh guru (Trygu, 2020). Selain itu, siswa yang memiliki motivasi belajar akan menunjukkan sikap positif terhadap suatu objek berupa gairah atau perasaan senang dan semangat di dalam belajar (Rizqi, Yusmansyah, \& Mayasari, 2018). Dalam penelitian yang dilakukan oleh Erlisnawati (2015) ditemukan bahwa anak yang memiliki motivasi rendah dalam belajar terlihat dari perilaku antara lain cenderung cepat bosan dengan kegiatan belajar, cepat menyerah, tidak ada keinginan untuk bertanya, kurang semangat dalam belajar, perhatiannya tidak fokus pada tujuan pembelajaran, dan tidak memiliki keinginan untuk meningkatkan prestasi belajar. Saat melakukan penelitian di salah satu Sekolah Dasar kelas 5 di Sangihe, Sulawesi Utara, ditemukan juga fakta bahwa selama pembelajaran daring, siswa kurang aktif dan tidak begitu tertarik kepada penyajian materi dan pertanyaan yang diberikan oleh guru. Terlihat siswa diam saja selama penyampaian materi, tidak ada yang mengajukan pertanyaan saat diberikan kesempatan untuk bertanya, dan sebagian besar tidak menjawab pertanyaan guru. Kurangnya motivasi selama belajar berdampak hingga akhir pembelajaran. Siswa pada akhirnya kurang memberi perhatian kepada guru hingga akhir pembelajaran. Berdasarkan observasi yang dilakukan, salah satu penyebab yang membuat siswa kurang termotivasi adalah guru melakukan penjelasan materi secara verbal dengan media yang lebih banyak menggunakan kata-kata atau teks sehingga siswa kehilangan fokus dan terlihat kurang tertarik atas pelajaran yang disampaikan.

Selama proses pembelajaran, salah satu pihak yang dapat mendorong tumbuhnya motivasi belajar siswa di kelas adalah guru. Kesadaran penting bahwa setiap siswa berharga dan terus berkembang harus dimiliki oleh guru dalam menuntun siswa selama belajar. Guru akan semakin antisipatif ketika mengenali keunikan atau karakteristik setiap siswa sehingga guru dapat menciptakan pembelajaran yang dapat memenuhi kebutuhan setiap siswa. Guru perlu mengetahui saat dimana siswa perlu untuk dimotivasi selama belajar. Guru punya andil dalam meningkatkan motivasi belajar siswa baik intrinsik maupun secara ekstrinsik. Dalam membangun motivasi belajar, guru perlu untuk menghadirkan variasi pembelajaran yang dapat membangun 
1179 Penerapan Media Pembelajaran Visual dalam Membangun Motivasi Belajar Siswa Sekolah Dasar Yonathan Hae, Year Rezeki Patricia Tantu, Widiastuti

DOI: https://doi.org/10.31004/edukatif.v3i4.522

motivasi belajar siswa serta terus memberikan dorongan berupa penguatan kepada siswa agar mengikuti pembelajaran dengan baik.

Untuk menjawab permasalahan yang terjadi di kelas, peneliti berefleksi dan menentukan langkah agar dapat membuat siswa kelas 5 SD lebih termotivasi dalam belajar. Guru merancang pembelajaran dengan mendesain media pembelajaran yang sesuai dengan kebutuhan siswa serta menghadirkan pembelajaran yang hidup melalui penguatan dan bimbingan yang diberikan saat guru berinteraksi dengan siswa. Berdasarkan teori perkembangan kognitif Jean Piaget, siswa yang duduk di kelas 5 SD sudah dapat berpikir secara logis tetapi masih terbatas pada hal yang bersifat konkrit (Eggen \& Kauchak, 2016). Dalam mengakses informasi pembelajaran, guru perlu menggunakan media yang sesuai dengan kebutuhan siswa pada usianya. Hal ini didukung dengan temuan yang menyatakan bahwa motivasi belajar dapat dibangun melalui penggunaan media belajar salah satunya adalah media pembelajaran visual (Bambang, Husain, \& Rede, 2015). Menurut Satrianawati (2018), media pembelajaran visual merupakan suatu media yang digunakan melalui indera penglihatan berupa gambar, komik, poster, majalah, miniatur, alat peraga dan sebagainya. Media seperti ini pada dasarnya dibuat dengan tujuan untuk mempermudah para siswa memahami konsep materi, menarik perhatian dan menjadikan mereka lebih semangat atau aktif dalam belajar. Hal tersebut sesuai dengan penelitian yang dilakukan oleh Nurdiyanti (2019) dengan temuan bahwa media visual dapat meningkatkan minat belajar anak, kreativitas, dan keaktifan anak didalam kelas.

Berdasarkan penelitian yang terdahulu, peneliti merancang media visual dengan mengikuti empat tahapan, yakni 1) tahapan persiapan. Pada tahapan ini guru mempersiapkan media pembelajaran visual yang sesuai dengan tujuan yang ingin dicapai dengan memperhatikan kondisi penggunaan media. 2) tahapan penggunaan. Pada tahapan ini guru menggunakan media pembelajaran dengan tetap menjaga fokus agar perhatian siswa tetap ada. 3) tahapan evaluasi. Pada tahapan ketiga ini, guru melakukan umpan balik pembelajaran berdasarkan media pembelajaran visual yang telah digunakan sebelumnya seperti penilaian, pemberian kesimpulan (tanya jawab), dan sebagainya. Melalui hal itu secara tidak langsung dapat diketahui hal-hal yang menjadi perbaikan media pembelajaran ke depan. 4) tindak lanjut. Pada tahapan ini guru memperdalam pemahaman siswa dengan pemberian tugas rumah dan kegiatan lainnya berkaitan dengan media belajar yang dibuat. Tahapan ini dibuat dengan modifikasi dari strategi yang sudah dilakukan oleh Purnaningsih (2017) saat menerapkan media pembelajaran yang dapat meningkatkan hasil belajar siswa. Selain itu, penerapan media belajar visual akan mengikuti 3 prinsip, yaitu kesederhanaan, penekanan, dan keterpaduan (Sumiharsono \& Hasanah, 2017). Penerapan media pembelajaran visual untuk siswa SD kelas 5 bukan hanya sekedar memberikan gambar-gambar tanpa tujuan kepada siswa, tetapi peneliti menggunakan tahapan dan prinsip yang dapat membuat media pembelajaran visual menjadi lebih efektif dimaknai oleh siswa terutama saat pembelajaran daring berlangsung.

Berdasarkan permasalahan dan kajian teoritik yang dikemukakan di atas, maka tujuan penulisan artikel ini adalah untuk mendeskripsikan penerapan media pembelajaran visual dalam membangun motivasi belajar siswa SD kelas 5. Manfaat dari penelitian yang dapat diperoleh diantaranya adalah siswa sekolah dasar dapat memiliki motivasi belajar di masa pembelajaran daring melalui penerapan media pembelajaran visual serta guru dapat berinovasi menciptakan pembelajaran aktif, kreatif, dan menyenangkan bagi siswa.

\section{METODE PENELITIAN}

Penelitian ini menggunakan pendekatan deskriptif kualitatif pada siswa kelas 5 SD di sekolah swasta yang ada di Sangihe, Sulawesi Utara. Penelitian dilakukan selama 2 bulan, yaitu pada bulan Juli - Agustus 2020. Subjek penelitian berjumlah 24 siswa. Peneliti bertindak sebagai pengamat yang merancang pembelajaran serta melaksanakan pembelajaran di kelas. Peneliti dibantu oleh salah seorang guru senior yang 
1180 Penerapan Media Pembelajaran Visual dalam Membangun Motivasi Belajar Siswa Sekolah Dasar Yonathan Hae, Year Rezeki Patricia Tantu, Widiastuti

DOI: https://doi.org/10.31004/edukatif.v3i4.522

bertindak sebagai pengamat juga selama pembelajaran berlangsung. Penelitian dibagi menjadi empat tahapan, yaitu tahapan observasi masalah, penerapan solusi, pengolahan data, dan penulisan laporan penelitian.

Teknik pengumpulan data dalam penelitian ini adalah dengan melakukan observasi, studi dokumentasi, dan refleksi. 1) Observasi yang dilakukan adalah pengamatan seluruh proses pembelajaran yang terjadi dalam kelas menggunakan lembar observasi sehingga menemukan variabel motivasi belajar sebagai variabel masalah yang akan dibahas dan melihat bagaimana efektivitas penerapan dari media pembelajaran visual dalam membangun motivasi belajar siswa. 2) Studi dokumentasi dalam penelitian ini adalah dengan melihat bukti media pembelajaran visual yang disajikan oleh guru serta melihat bukti kerja dari siswa. 3) Refleksi dalam penelitian ini merupakan hasil refleksi guru atas pembelajaran yang dilakukan saat menerapkan media pembelajaran visual dalam membangun motivasi belajar siswa. Data yang dikumpulkan kemudian dianalisa secara kualitatif merujuk kepada variabel motivasi belajar dan media pembelajaran visual, setelah itu diinterpretasikan berdasarkan kajian teori yang ditulis. Data-data yang dikumpulkan divalidasi dengan menggunakan triangulasi data dan mendapat persetujuan ahli, yaitu guru senior yang bertindak sebagai pengamat dalam kelas penelitian.

\section{HASIL DAN PEMBAHASAN PENELITIAN}

Peranan media pembelajaran sangat penting dalam membangun motivasi belajar siswa dalam kelas. Setelah mengamati permasalahan yang terjadi pada siswa SD kelas 5 di salah satu sekolah di Sangihe, Sulawesi Utara, yaitu siswa kurang menunjukkan indikator motivasi belajar saat pembelajaran daring, seperti siswa mengantuk, tidak memberikan perhatian, kurang aktif dan tidak begitu tertarik dalam pembelajaran. Oleh karena itu, peneliti mulai menerapkan solusi yaitu menyajikan media pembelajaran visual saat mengajar dalam kelas. Hal ini sesuai dengan penelitian sebelumnya dari Sugiasih (2015) yang menyatakan bahwa salah satu faktor yang mempengaruhi motivasi belajar yakni adanya penerapan media belajar yang dilakukan oleh guru. Penerapan media belajar visual dipraktekkan dengan mengikuti beberapa tahapan, yaitu tahap persiapan, tahap penggunaan, tahap evaluasi, dan tindak lanjut.

Tahapan pertama yang dilakukan adalah tahapan persiapan. Peneliti merancang dan menyajikan media pembelajaran visual dengan mempertimbangkan karakteristik anak usia SD kelas 5. Peneliti menyajikan materi pembelajaran dengan media powerpoint yang memiliki desain menarik. Media PPt tersebut dikombinasikan dengan gambar-gambar dalam bentuk puzzle yang kreatif untuk menarik perhatian siswa. Media yang dipilih oleh guru adalah media yang dapat diproyeksikan, yaitu media yang menggunakan alat proyeksi sehingga gambar terlihat pada screen atau layar. Tahapan kedua yang dilakukan adalah tahap penggunaan. Peneliti menggunakan fitur share screen sehingga gambar pada PPt dapat terlihat pada layar siswa. Penerapan media pembelajaran visual dengan menggunakan teknologi ini sesuai dengan temuan pada penelitian yang dikemukakan oleh Wahyugi \& Fatmariza (2021) yang menyatakan bahwa media pembelajaran dengan memadukan unsur teknologi dapat meningkatkan kualitas pembelajaran. Gambar yang dibuat dengan menggunakan sentuhan teknologi digital dapat memberikan kesan yang nyata bagi siswa. 
1181 Penerapan Media Pembelajaran Visual dalam Membangun Motivasi Belajar Siswa Sekolah Dasar Yonathan Hae, Year Rezeki Patricia Tantu, Widiastuti

DOI: https://doi.org/10.31004/edukatif.v3i4.522

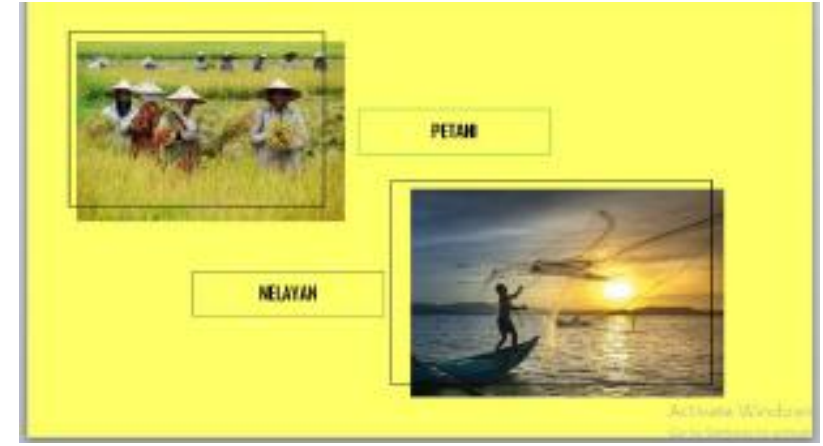

Gambar 1: Contoh slide PPt yang menggunakan gambar

Penerapan media visual yang dipilih tidak lepas dari tiga prinsip efektif, yaitu kesederhanaan, keterpaduan, dan penekanan. Pertama, prinsip kesederhanaan dalam penyajian media belajar visual, yaitu guru mendesain suatu media visual berdasarkan jumlah elemen yang ada di dalamnya. Jumlah elemen yang sangat banyak akan membuat siswa sulit untuk membagi fokus atau perhatiannya pada media visual yang disajikan. Dalam penelitian ini, guru tidak banyak menggunakan kata-kata atau teks yang panjang dalam slide, tetapi menyajikan gambar yang cocok dengan topik yang sedang dipelajari agar siswa dapat lebih tertarik dan muncul rasa ingin tahu dari gambar yang dilihat sehingga dapat membuat siswa fokus dalam belajar. Penyederhanaan kata-kata yang didukung oleh gambar yang menarik sangat membantu siswa untuk mengikuti pembelajaran dengan baik. Kedua, prinsip keterpaduan adalah perpaduan antara beberapa elemen berupa gambar, warna, tulisan, dan sebagainya yang dibuat menjadi satu kesatuan yang seimbang. Pemilihan warna latar belakang pada media PPt, warna tulisan, serta gambar yang dimasukkan perlu ada keserasian sehingga dapat menjadi daya tarik bagi siswa untuk tetap mengikuti pembelajaran. Peneliti memilih warna dasar yang cerah dan warna tulisan yang gelap sehingga siswa dapat membaca tulisan dengan jelas. Warna gambar yang dipilih serasi dengan warna dasar latar belakang yang ada di PPt. Ketiga, prinsip penekanan perlu dipertimbangkan dalam menerapkan media pembelajaran visual. Guru membuat penekanan pada bagianbagian penting yang merupakan inti dari materi yang dibahas sehingga siswa dapat mengingat poin penting atau manfaat dari pembelajaran yang diikuti. Hal ini dibantu dengan desain berupa warna yang berbeda atau simbol yang menarik. Guru menggunakan animasi serta kotak yang dapat membantu siswa melihat poin penting yang sedang diberikan. Dengan mengikuti ketiga prinsip yang dijelaskan maka guru dapat menyajikan media visual yang sesuai dengan karakteristik siswa sekolah dasar. Selain itu, saat media visual disajikan selama pembelajaran, guru berperan untuk terus mengarahkan siswa dan menjaga fokus siswa selama pembelajaran daring.

Tahapan ketiga yang dilakukan adalah tahapan evaluasi. Pada tahapan ini, guru melakukan tanya jawab dengan siswa berupa pemberian kuis dan tanya jawab sesuai dengan topik yang dibahas. Kuis dirancang juga dengan menarik dan menggunakan gambar sehingga siswa dapat terus tertarik memperhatikan pembelajaran. Setelah itu, tahapan keempat yang dilakukan adalah pemberian aktivitas tambahan yang dapat memperkuat pemahaman siswa mengenai topik yang dibahas. 
1182 Penerapan Media Pembelajaran Visual dalam Membangun Motivasi Belajar Siswa Sekolah Dasar Yonathan Hae, Year Rezeki Patricia Tantu, Widiastuti

DOI: https://doi.org/10.31004/edukatif.v3i4.522

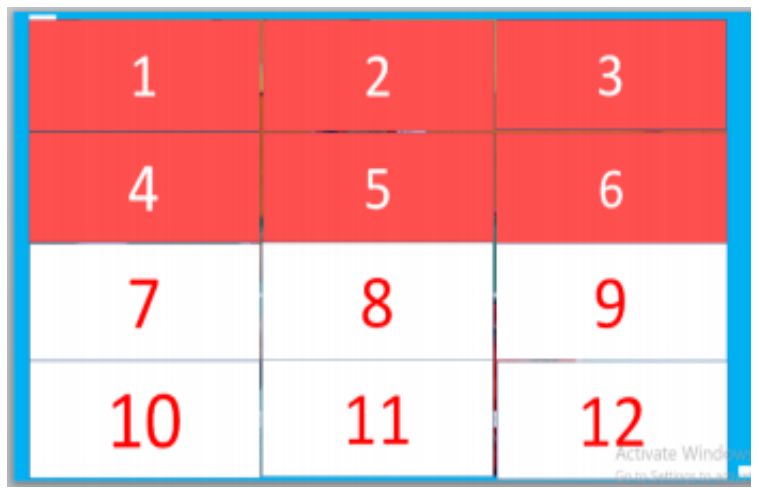

Gambar 2: Contoh Slide PPt Kuis Bergambar

Berdasarkan hasil observasi selama pembelajaran berlangsung, terlihat saat guru menyajikan materi dengan menggunakan media pembelajaran visual, siswa-siswa kelas 5 SD antusias untuk mengikuti dan menyelesaikan pembelajaran yang ada. Sebagai bukti dalam jurnal refleksi mengajar yang dilakukan guru sebanyak enam kali diperoleh adanya indikator motivasi siswa yang semakin terbangun. Pada jurnal refleksi pertama dan kedua, diperoleh bahwa siswa-siswa mengajukan pertanyaan terkait gambar yang diberikan dan mereka juga terdorong untuk menjawab pertanyaan-pertanyaan. Saat guru menyajikan pertanyaan-pertanyaan dalam sebuah gambar berbentuk puzzle. Siswa tertarik untuk berpikir dan merefleksikan kegiatan sehari-hari mereka. Pembelajaran menjadi berbeda dengan sebelumnya karena siswa mengikutinya dengan antusias. Selain siswa dapat termotivasi belajar, mereka juga dapat lebih memahami materi yang ada. Para siswa meminta guru untuk terus memberikan pertanyaan-pertanyaan yang lain untuk dapat dikerjakan. Hal ini sesuai dengan penelitian dari Nurdiyanti (2019) yang mengatakan bahwa media visual berupa gambar atau foto memiliki salah satu kelebihan, yaitu bersifat konkret dan lebih realistis atau terlihat nyata. Ketika siswa kelas 5 SD belajar tentang petani dan guru menyajikan materi dengan gambar petani yang sedang bertani di sawah, mengumpulkan padi, menggunakan caping, dan membawa peralatan lainnya, siswa dapat membayangkan kondisi nyata bagaimana petani bekerja sehari-hari. Hal ini sangat memberi manfaat bagi siswa dalam mengembangkan kemampuan berpikirnya dan mendorong rasa ingin tahu siswa untuk bertanya tentang aktivitas petani sehari-hari. Kemudian berlanjut pada jurnal refleksi tiga sampai enam, guru juga menerapkan media pembelajaran visual secara menarik sesuai dengan karakteristik dan tujuan pembelajaran yang ingin dicapai. Terlihat siswa begitu aktif dan memberikan perhatian dalam pembelajaran yang berlangsung. Hal ini terbukti dari adanya para siswa yang terus bersemangat dalam mengerjakan atau menjawab pertanyaan yang diberikan.

Hasil refleksi peneliti menyatakan bahwa penerapan media pembelajaran visual membuat suasana pembelajaran dalam kelas menjadi berbeda. Siswa antusias mengikuti pembelajaran dari awal hingga akhir. Namun, penting juga bagi guru untuk terus mengarahkan dan memanajemen kelas sehingga semua siswa dapat aktif dalam belajar. Guru mengingatkan siswa melalui aturan kelas untuk tetap dapat menghargai saat pembelajaran dan guru juga berstrategi untuk mendahulukan siswa yang terlihat pasif agar mendapatkan kesempatan untuk bisa bertanya dan menjawab.

Berdasarkan hasil penelitian yang sudah dipaparkan di atas, terlihat bahwa para siswa menunjukkan indikator motivasi belajar saat pembelajaran berlangsung menggunakan media pembelajaran visual. Para siswa kelas 5 SD termotivasi dengan adanya media pembelajaran visual yang diterapkan oleh guru selama proses pembelajaran. Adapun hal yang mendukung penerapan media pembelajaran visual menjadi efektif adalah guru bukan hanya melakukan tahap persiapan, yaitu merancang media visual dengan kreatif dan menarik, tetapi perlu melakukan tahap-tahap selanjutnya. Tahap kedua yang perlu diperhatikan, yaitu tahap penggunaan. Guru perlu memiliki keterampilan berkomunikasi yang baik dalam mengarahkan siswa saat media pembelajaran visual ditampilkan. Selanjutnya, tahap ketiga atau tahap evaluasi, guru perlu melakukan evaluasi dengan mengecek pemahaman siswa seperti penilaian, pemberian kesimpulan (tanya jawab), dan 
1183 Penerapan Media Pembelajaran Visual dalam Membangun Motivasi Belajar Siswa Sekolah Dasar Yonathan Hae, Year Rezeki Patricia Tantu, Widiastuti

DOI: https://doi.org/10.31004/edukatif.v3i4.522

sebagainya. Dengan adanya tahap ini, guru pun dapat mengevaluasi efektivitas dari media pembelajaran yang diberikan dalam kelas. Kemudian, pada tahap terakhir atau tahap tindak lanjut, guru dapat memperkuat pemahaman siswa dengan memberikan tambahan aktivitas terkait topik yang dijelaskan. Melalui hal tersebut, media visual dapat terus dikembangkan sesuai tujuan pembelajaran dan siswa pun tidak menjadi bosan dengan adanya media visual yang tidak monoton dalam pembelajaran.

Slavin (2018) mengemukakan beberapa usaha untuk meningkatkan motivasi intrinsik siswa adalah dengan cara membangkitkan minat, mempertahankan rasa ingin tahu, serta menyajikan materi yang menarik. Sedangkan untuk meningkatkan motivasi ekstrinsik, guru perlu memberikan tujuan pembelajaran yang jelas, umpan balik yang jelas, serta memberikan penguatan atau pujian kepada siswa. Dalam penelitian ini, peneliti melakukan kombinasi dari peningkatan motivasi secara intrinsik dan ekstrinsik. Selain guru menerapkan media pembelajaran visual kepada siswa, guru juga selalu memberikan umpan balik atas jawaban siswa dan tugas yang dikerjakan oleh siswa, serta guru memberikan penguatan berupa apresiasi kepada siswa yang mengikuti pembelajaran dengan baik serta dorongan semangat untuk siswa yang masih pasif. Hal ini sesuai dengan penelitian yang dilakukan di salah satu SD di Magelang yang mendapat temuan bahwa motivasi belajar pada siswa tidak hanya diperoleh melalui faktor ekstrinsik sendiri maupun faktor intrinsik saja, tetapi perlu kombinasi dari kedua faktor tersebut (Indah et al., 2020).

Dengan demikian, penerapan media pembelajaran visual yang diterapkan berdasarkan kolaborasi prinsip, tujuan pembelajaran dan tahapan-tahapan penerapan, dapat membuat media berperan lebif efektif sebagai bentuk rangsangan untuk membangun motivasi belajar siswa dan menjadi sarana inovasi guru dalam menciptakan pembelajaran yang menarik bagi para siswa selama pembelajaran daring berlangsung. Media visual tidak hanya dapat meningkatkan motivasi belajar saat tatap muka saja, tetapi juga dapat meningkatkan motivasi belajar siswa saat pembelajaran daring. Di tengah-tengah berkembangnya teknologi digital sekarang ini, guru perlu terus kreatif menciptakan pembelajaran yang dapat menjawab kebutuhan siswa di zaman ini. Dengan mempertimbangkan aspek visual saat menyajikan pembelajaran, guru dapat menolong siswa-siswa menjadi lebih berimajinasi dan kreatif berpikir. Adapun keterbatasan dari temuan ini adalah hanya diterapkan pada satu mata pelajaran saja, yaitu tematik. Sebagai pengembangan lanjutan, penerapan media visual ini dapat diujicobakan pada kelompok mata pelajaran lain yang diampu oleh anak SD sehingga dapat memperkuat hasil yang menyatakan bahwa media visual dapat meningkatkan motivasi belajar siswa.

\section{KESIMPULAN}

Penerapan media pembelajaran visual dapat membangun motivasi belajar siswa kelas 5 SD selama pembelajaran daring berlangsung. Penerapan media pembelajaran visual efektif dalam penggunaannya karena dibuat menggunakan tiga prinsip, yaitu kesederhanaan media, keterpaduan elemen-elemen yang ada dalam media, serta penekanan bagian-bagian penting dalam media pembelajaran. Selain itu, penyajian media pembelajaran juga dibuat dan disusun menggunakan 4 tahapan, yaitu tahapan persiapan, tahapan penggunaan, tahapan evaluasi, dan tindak lanjut. Hal ini penting untuk diperhatikan para guru saat menyajikan media pembelajaran kepada siswa. Media visual yang berisikan gambar dapat membuat siswa tertarik dalam belajar, lebih memahami materi yang diberikan, dan aktif hingga akhir pembelajaran. Media pembelajaran visual yang efektif tidak sekedar dilihat dari kecanggihan maupun kemewahan media yang dibuat, tetapi bagaimana media dapat membantu tercapainya tujuan pembelajaran karena dibuat dengan prinsip-prinsip yang sesuai dengan karakteristik siswa.

\section{UCAPAN TERIMA KASIH}

Terima kasih kepada LPPM Universitas Pelita Harapan yang sudah mendanai publikasi jurnal ini. 
1184 Penerapan Media Pembelajaran Visual dalam Membangun Motivasi Belajar Siswa Sekolah Dasar Yonathan Hae, Year Rezeki Patricia Tantu, Widiastuti

DOI: https://doi.org/10.31004/edukatif.v3i4.522

\section{DAFTAR PUSTAKA}

Badaruddin, A. (2015). Peningkatan Motivasi Belajar Siswa Melalui Konseling Klasikal. Jakarta: CV Abe Kreatifindo.

Bambang, L., Husain, S. N., \& Rede, A. (2015). Penerapan pembelajaran media audio-visual untuk meningkatkan motivasi dan hasil belajar pada mata pelajaran biologi di kelas viii a smp gkst imanuel palu. Jurnal Sains dan Teknologi Tadulako, 4(1), 23-28.

Eggen, P., \& Kauchak, D. (2016). Educational Psychology: Windows on Classrooms (10 ed.). Boston: Pearson.

Emda, A. (2018). Kedudukan Motivasi Belajar Siswa Dalam Pembelajaran. Lantanida Journal, 5(2), 172. https://doi.org/10.22373/lj.v5i2.2838

Erlisnawati. (2015). Masalah Motivasi Belajar Siswa Sd Pada Ips Erlisnawati Fkip Universitas Riau. Jurnal Pendidikan Sekolah Dasar (JPsd), Vol.1(2), 1-10.

Indah, M. Y. N., Yanti, M. M., Arifi, Y., Pawestri, A. A. M., \& Hermahayu, H. (2020). Motivasi Belajar Siswa Sekolah Dasar Di Kota Magelang. Jurnal VARIDIKA, 32(1), 61-69. https://doi.org/10.23917/varidika.v32i1.11141

Makki, M. I., \& Aflahah. (2019). Konsep Dasar Belajar dan Pembelajaran. Jawa Timur: Duta Media Publishing.

Nurdiyanti, S. (2019). Implementasi Media Visual Dan Audiovisual Terhadap Pembelajaran Anak Usia Dini Di Era Revolusi Industri 4 . 0. Universitas Sultan Ageng Tirtayasa, 2(1), 642-650.

Purnaningsih, P. (2017). Strategi Pemanfaatan Media Audio Visual untuk Peningkatan Hasil Belajar Bahasa $\begin{array}{lllll}\text { Inggris. Jurnal Informatika Universitas } & \text { Pamulang, } & 2(1), & 34 .\end{array}$ https://doi.org/10.32493/informatika.v2i1.1503

Rizqi, A. A., Yusmansyah, \& Mayasari, S. (2018). Faktor-Faktor yang Mempengaruhi Motivasi Belajar. Jurnal FKIP Universitas, 6(2), 1-14.

Satrianawati. (2018). Media dan Sumber Belajar. Yogyakarta: Deepublish.

Slavin, R. E. (2018). Educational Psychology: Theory into practice (12 ed.). Pearson.

Sugiasih, P. (2015). Pengaruh peran guru sebagai motivator terhadap motivasi belajar Ekonomi siswa SMA Se-kecamatan Seririt tahun pelajaran 2014/2015. Jurnal Jurusan Pendidikan Ekonomi (JJPE), 5(1), 111.

Sumiharsono, R., \& Hasanah, H. (2017). Media Pembelajaran. Jember: Pustaka Abadi.

Trygu. (2020). Studi Literatur Problem Based Learning untuk Masalah Motivasi bagi Siswa dalam Belajar Matematika. Depok: Guepedia.

Wahyugi, R., \& Fatmariza, F. (2021). Pengembangan Multimedia Interaktif Menggunakan Software Macromedia Flash 8 Sebagai Upaya Meningkatkan Motivasi Belajar Siswa Sekolah Dasar. Edukatif: Jurnal Ilmu Pendidikan, 3(3), 791-800. 